Article

\title{
Lupane Triterpenes from the Leaves of Acanthopanax gracilistylus
}

\author{
Xiao-Jun Li ${ }^{1,2,+}$, Qin-Peng Zou ${ }^{3,+}$, Xiang Wang ${ }^{1}$, Kwan-Woo Kim ${ }^{2}$, Mao-Fang Lu ${ }^{1}$, \\ Sung-Kwon Ko ${ }^{4}$, Chang-Soo Yook ${ }^{5}$, Youn-Chul Kim ${ }^{2, *}$ and Xiang-Qian Liu ${ }^{1, *}$ \\ 1 School of Pharmacy, Hunan University of Chinese Medicine, Changsha 410208, Hunan, China; \\ lixiaojun2017@yahoo.com (X.-J.L.); hzywtlwx@163.com (X.W.); lumf7983@126.com (M.-F.L.) \\ 2 College of Pharmacy, Wonkwang University, Iksan 570-749, Korea; swamp1@naver.com \\ 3 Broad-Ocean Bio-Science and Technique Co., Ltd. of Changsha, Changsha 410205, Hunan, China; \\ zouqinpeng@163.com \\ 4 Department of Oriental Medical Food \& Nutrition, Semyung University, Jecheon 27136, Korea; \\ skko@semyung.ac.kr \\ 5 School of Pharmacy, KyungHee University, Seoul 130-701, Korea; yookcs@khu.ac.kr \\ * Correspondence: yckim@wku.ac.kr (Y.-C.K.); lxq0001cn@163.com (X.-Q.L.); \\ Tel.: +82-63-850-6823 (Y.-C.K.); +86-731-8845-8240 (X.-Q.L.) \\ $\dagger$ These authors contribute equally to this work.
}

Received: 1 December 2017; Accepted: 29 December 2017; Published: 1 January 2018

\begin{abstract}
The phytochemical study on the leaves of Acanthopanax gracilistylus (Araliaceae) resulted in the discovery of a new lupane-triterpene compound, acangraciligenin $S$ (1), and a new lupane-triterpene glycoside, acangraciliside $S$ (2), as well as two known ones, $3 \alpha, 11 \alpha$ - dihydroxy-lup-20(29)-en-23,28-dioic acid (3) and acankoreoside C (4). Their chemical structures were elucidated by mass, 1D- and 2D-nuclear magnetic resonance (NMR) spectroscopy. The chemical structures of the new compounds 1 and 2 were determined to be $1 \beta, 3 \alpha$-dihydroxy-lup-20(29)-en-23, 28-dioic acid and 1 $\beta, 3 \alpha$-dihydroxy-lup-20(29)-en-23,28-dioic acid 28-O-[ $\alpha$-L-rhamnopyranosyl-( $1 \rightarrow 4)-\beta$-D-glucopyranosyl-( $1 \rightarrow 6)-\beta$-D-glucopyranosyl] ester, respectively. The anti-neuroinflammatory activity of the selective compounds, $\mathbf{1}$ and $\mathbf{3}$, were evaluated with lipopolysaccharide (LPS)-induced BV2 microglia. The tested compounds showed moderate inhibitory effect of nitric oxide (NO) production.
\end{abstract}

Keywords: Acanthopanax gracilistylus; Araliaceae; lupane-triterpene; acangraciligenin S; acangraciliside $S$

\section{Introduction}

Acanthopanax gracilistylus W. W. Smith belongs to Araliaceae, which is widely distributed in China, and its dried roots and stem barks are listed officially in the Chinese Pharmacopoeia (2015 edition) as Acanthopanax Cortex (named as Wujiapi), which has been used as medicine for the treatment of paralysis, arthritis, rheumatism, lameness, and liver disease [1-3]. Previous phytochemical investigations of this plant have led to the identification of triterpenoids [4-7], diterpenoids [8,9], monoterpenoids [10-12], lignans [12], steroids, cerebrosides [13], and volatile components [10,14-19], which showed diverse biological activities, such as anti-tumor [20,21], anti-inflammatory [22-24], and liver protective effects [3]. As part of our ongoing research to identify bioactive substances from the genus Acanthopanax, we investigated a $\mathrm{MeOH}$ extract of the leaves of $A$. gracilistylus and identified two new lupane triterpenoids ( 1 and 2 ), and two known compounds ( 3 and 4 ) by using high-speed countercurrent chromatography (HSCCC) in conjunction with a high-performance liquid 
chromatography (HPLC) isolation system (Figure 1). In this paper, the isolation and structural elucidation of the new isolates, as well as an evaluation of their bio-activities, are reported.

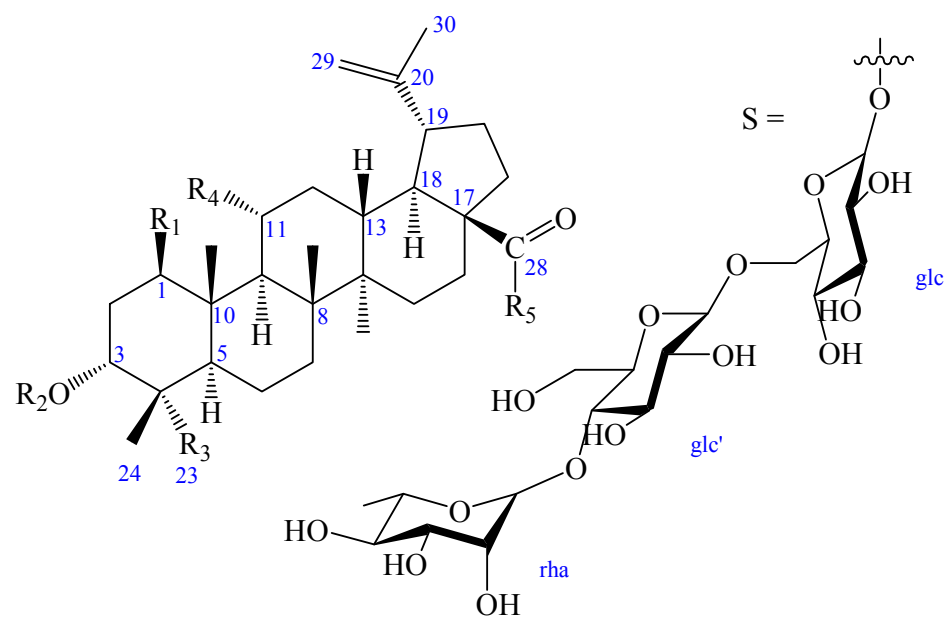

\begin{tabular}{cccccc}
\hline & $\mathbf{R}_{\mathbf{1}}$ & $\mathbf{R}_{\mathbf{2}}$ & $\mathbf{R}_{\mathbf{3}}$ & $\mathbf{R}_{\mathbf{4}}$ & $\mathbf{R}_{\mathbf{5}}$ \\
\hline $\mathbf{1}$ & $\mathrm{OH}$ & $\mathrm{OH}$ & $\mathrm{COOH}$ & $\mathrm{H}$ & $\mathrm{OH}$ \\
$\mathbf{2}$ & $\mathrm{OH}$ & $\mathrm{OH}$ & $\mathrm{COOH}$ & $\mathrm{H}$ & $\mathrm{S}$ \\
$\mathbf{2 a}$ & $\mathrm{OH}$ & $\mathrm{OH}$ & $\mathrm{COOH}$ & $\mathrm{H}$ & $\mathrm{OH}$ \\
$\mathbf{3}$ & $\mathrm{H}$ & $\mathrm{OH}$ & $\mathrm{COOH}$ & $\mathrm{OH}$ & $\mathrm{OH}$ \\
$\mathbf{4}$ & $\mathrm{H}$ & $-\beta$-D-glc & $\mathrm{CH}_{3}$ & $\mathrm{OH}$ & $\mathrm{S}$ \\
\hline
\end{tabular}

Figure 1. Chemical structures of compounds 1-4.

\section{Results and Discussion}

Compound 1 was obtained as a colorless needle, m.p. $282.6^{\circ} \mathrm{C}$, and gave a positive reaction in the Liebermann-Burchard test. Its molecular formula of $\mathrm{C}_{30} \mathrm{H}_{46} \mathrm{O}_{6}$ was determined on the basis of ESI-MS at $m / z=501.3[\mathrm{M}-\mathrm{H}]^{-}$(negative) and HR-ESI-MS at $m / z=501.3221[\mathrm{M}-\mathrm{H}]^{-}$(calcd. for $\mathrm{C}_{30} \mathrm{H}_{45} \mathrm{O}_{6}$ : 501.3222), indicating eight degrees of unsaturation. The ${ }^{1} \mathrm{H}-\mathrm{NMR}$ spectrum of $\mathbf{1}$ (in acetone- $d_{6}$ ) showed the following signals: five tertiary methyl groups at $\delta 0.97,0.99,1.07,1.17$ and 1.71 (each $3 \mathrm{H}, \mathrm{s}$ ); two olefinic protons at $\delta 4.58(1 \mathrm{H}, \mathrm{m})$ and $4.72(1 \mathrm{H}, \mathrm{d}, J=1.68 \mathrm{~Hz})$; two hydroxy-substituted methines at $\delta 3.82(1 \mathrm{H}, \mathrm{t}, J=2.40 \mathrm{~Hz})$ and $3.84(1 \mathrm{H}, \mathrm{dd}, J=8.16,3.96 \mathrm{~Hz})$. The ${ }^{13} \mathrm{C}-\mathrm{NMR}$ and distortionless enhancement by polarization transfer (DEPT) spectra revealed 30 carbon signals. The skeleton of 1 was recognized to be lupane triterpenoid by ${ }^{1} \mathrm{H}$ - and ${ }^{13} \mathrm{C}-\mathrm{NMR}$ analysis (see Table 1 ), with the typical olefinic carbons at $\delta 151.89$ (C-20) and 110.26 (C-29), five quaternary methyl carbons at $\delta 13.24,15.40$, $17.31,17.92$, and 19.72, two oxymethine carbons at $\delta 73.99$ and 75.46 , and two carboxyl signals at $\delta 177.84$ and 178.16, respectively. The assignment of the $\alpha$-hydroxyl group at C-3 was performed by comparing its spectral data with literature values [25-28]. The chemical shifts of C-3 ( $\delta 73.99)$ and C-4 ( $\delta$ 52.27) further confirmed the axial configuration of the 3-hydroxyl group by comparing with the corresponding data of the $3 \beta$-hydroxy-lup-20(29)-en-23,28-dioic acid [ $\delta$ values for 84.4 (C-3) and $43.0(\mathrm{C}-4)$ ] [29]. Additionally, the carbon chemical shifts of C-23 ( $\delta 178.16)$ and C-28 ( $\delta 177.84)$ were also similar to those of $3 \beta$-hydroxy-lup-20(29)-en-23,28-dioic acid [ $\delta$ values for 178.7 (C-23) and 177.3 (C-28)] suggesting that the two carboxyl groups were at C-23 and C-28 [29]. In heteronuclear multiple bond connectivity (HMBC) spectrum, the $\mathrm{H}-1$ proton signal at $\delta 3.84(1 \mathrm{H}, \mathrm{dd}, J=8.16,3.96 \mathrm{~Hz})$ correlated with carbons C-2 ( $\delta 37.36), C-9(\delta 52.98), C-10(\delta 44.33)$, and C-25 ( $\delta 13.24)$; protons H-2 at $\delta$ $1.82(1 \mathrm{H}, \mathrm{m})$ and $\mathrm{H}-25$ at $\delta 0.97(3 \mathrm{H}, \mathrm{s})$ correlated with carbon $\mathrm{C}-1(\delta 75.46)$; the $\mathrm{H}-3$ proton signal at $\delta$ $3.82(1 \mathrm{H}, \mathrm{t}, J=2.40 \mathrm{~Hz})$ correlated with carbons $\mathrm{C}-5(\delta 45.25)$ and C-23 $(\delta 178.16)$; protons $\mathrm{H}-2$ at $\delta 1.82$ $(1 \mathrm{H}, \mathrm{m})$ and $\mathrm{H}-24$ at $\delta 1.17(3 \mathrm{H}, \mathrm{s})$ correlated with carbon $\mathrm{C}-3(\delta 73.99) ;$ protons $\mathrm{H}-5$ at $\delta 1.95(1 \mathrm{H}, \mathrm{m})$ and $\mathrm{H}-24$ at $\delta 1.17(3 \mathrm{H}, \mathrm{s})$ correlated with carbon C-23 $(\delta 178.16)$; protons $\mathrm{H}-16$ at $\delta 1.48(1 \mathrm{H}, \mathrm{m}), \mathrm{H}-18$ 
at $\delta 1.64(1 \mathrm{H}, \mathrm{m})$, and $\mathrm{H}-22$ at $\delta 1.92(1 \mathrm{H}, \mathrm{m})$ correlated with carbon $\mathrm{C}-28(\delta 177.84)$; the correlations from $\mathrm{H}-29$ at $\delta 4.58(1 \mathrm{H}, \mathrm{m}, \mathrm{Ha})$ and $\delta 4.72(1 \mathrm{H}, \mathrm{d}, J=1.68 \mathrm{~Hz}, \mathrm{Hb})$ to $\mathrm{C}-19(\delta 48.24), \mathrm{C}-20(\delta 151.89)$, and C-30 ( $\delta 19.72)$; the correlations from $\mathrm{H}-30$ at $\delta 1.71(3 \mathrm{H}, \mathrm{s})$ to $\mathrm{C}-19(\delta 48.24), \mathrm{C}-20(\delta 151.89)$, and C-29 ( $\delta$ 110.26). These pieces of evidence confirmed that the double bond was at C-20/C-29 and the other hydroxyl group was at C-1 (Figure 2 and Table S1). The nuclear Overhauser enhancement spectroscopy (NOESY) spectrum of 1 showed the correlations between the proton of $\mathrm{H}-1$ and $\mathrm{H}-2_{\text {eq }}, \mathrm{H}-1$ and $\mathrm{H}-5$, $\mathrm{H}-1$, and H-9, H-1 and H-11 eq, suggesting that $\mathrm{H}-1$ was axial in orientation, which, in turn, suggested that the hydroxyl group at C-1 was $\beta$-positioned. Similarly, cross-peaks between H-24 and H-25, as well as H-3, H-3 and $\mathrm{H}-2_{e q}$ as well as $\mathrm{H}-2_{a x}$, which indicated that the methyl group (H-24) was axial and H-3 was equatorial, which, in turn, suggested that the hydroxyl group at C-3 and carboxyl group at C-4 were $\alpha$-positioned. Furthermore, cross-peaks between H-19 and H-13 confirmed that the isopropenyl group at C-19 was $\alpha$-positioned (Figure 3). Based on the above spectral data, the structure of 1 was determined as $1 \beta, 3 \alpha$-dihydroxy-lup-20(29)-en-23,28-dioic acid, a new compound named acangraciligenin $S$.

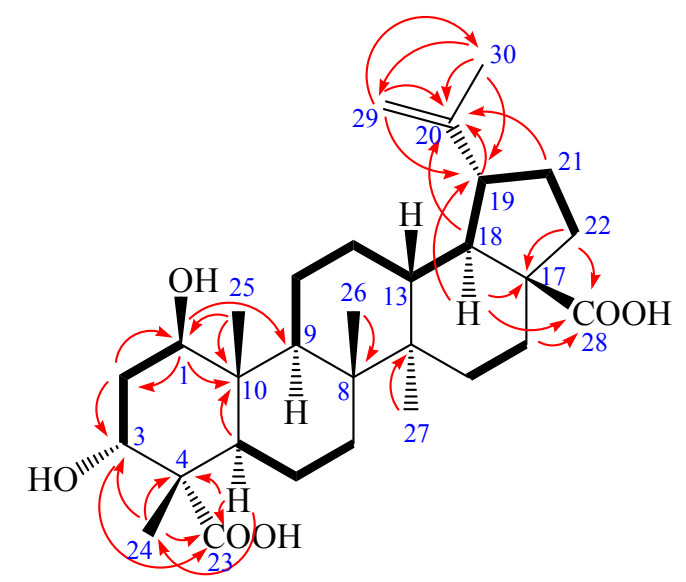

Figure 2. ${ }^{1} \mathrm{H}-{ }^{1} \mathrm{H}$ COSY (bold) and selected HMBC (arrow) correlations of $\mathbf{1}$.

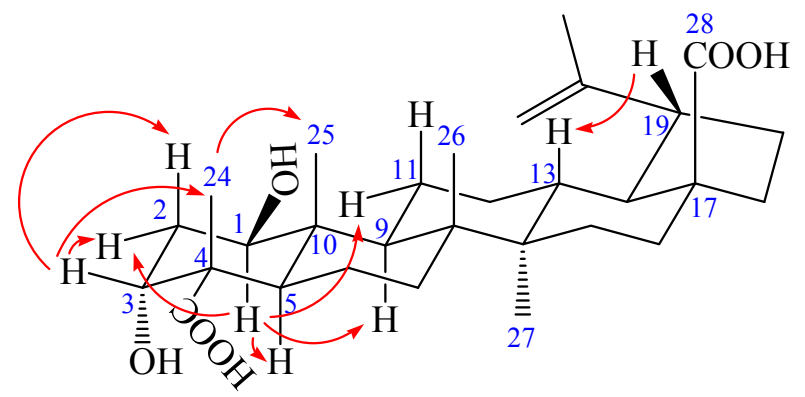

Figure 3. The key NOESY (arrow) correlations of $\mathbf{1}$.

Compound 2 was obtained as a white amorphous powder, m.p. $230.5^{\circ} \mathrm{C}$, and gave positive responses in Liebermann-Burchard and Molish tests. Its molecular formula of $\mathrm{C}_{48} \mathrm{H}_{76} \mathrm{O}_{20}$ was determined on the basis of ESI-MS at $m / z=972.5[\mathrm{M}]^{+}$and HR-ESI-MS at $m / z=971.4865[\mathrm{M}-\mathrm{H}]^{-}$ (negative) (calcd. for $\mathrm{C}_{48} \mathrm{H}_{75} \mathrm{O}_{20}$ : 971.4857), indicating eleven degrees of unsaturation. The ${ }^{1} \mathrm{H}-\mathrm{NMR}$ spectrum of 2 (in methanol- $d_{4}$ ) showed the following signals: five tertiary methyl groups at $\delta 0.95$, 0.98, 1.03, 1.09 and 1.70 (each $3 \mathrm{H}, \mathrm{s})$; one secondary methyl group at $\delta 1.25(3 \mathrm{H}, \mathrm{d}, J=4.96 \mathrm{~Hz})$, assigned to H-6" of the rhamnose; and two olefinic protons at $\delta 4.58(1 \mathrm{H}, \mathrm{brs})$ and $4.72(1 \mathrm{H}, \mathrm{brs})$; two hydroxy-substituted methines at $\delta 3.67(1 \mathrm{H}, \mathrm{m})$ and $3.80(1 \mathrm{H}, \mathrm{m})$. In addition, three anomeric protons were at $\delta 4.37(1 \mathrm{H}, \mathrm{d}, J=6.28 \mathrm{~Hz}), 4.84(1 \mathrm{H}$, overlapped), and $5.45(1 \mathrm{H}, \mathrm{d}, J=6.56 \mathrm{~Hz})$, suggesting the appearance of three sugar units. The ${ }^{13} \mathrm{C}-\mathrm{NMR}$ and DEPT spectra revealed 48 carbon 
signals, of which, 30 signals were assigned to a triterpenoid sapogenol moiety and 18 signals belong to three monosaccharide moieties. The aglycone of 2 was recognized to be lupane triterpene type by ${ }^{1} \mathrm{H}$ - and ${ }^{13} \mathrm{C}-\mathrm{NMR}$ analysis (see Table 1 ), with the typical olefinic carbons at $\delta 151.77$ (C-20) and 110.41 (C-29), five quaternary methyl carbons at $\delta 13.17,15.10,17.14,18.08$, and 19.49 , two oxymethine carbons at $\delta 74.14$ and 76.33, and two carboxyl signals at $\delta 176.40$ and 182.60, respectively. Compared with the ${ }^{1} \mathrm{H}$ - and ${ }^{13} \mathrm{C}-\mathrm{NMR}$ data of the aglycone of $\mathbf{2}$ and compound $\mathbf{1}$, the high similarity indicated that the aglycone of $\mathbf{2}$ was the same as that of compound $\mathbf{1}$. Assignments of the $\beta$-hydroxyl group at C-1 ( $\delta 76.33), \alpha$-hydroxyl group at C-3 ( $\delta 74.14)$, and two carboxyl groups at C-23 $(\delta 182.60)$ and C-28 ( $\delta 176.40)$ were performed by comparing its spectral data with compound $\mathbf{1}$ [ $\delta$ values for $75.46(\mathrm{C}-1)$, 73.99 (C-3), 178.16 (C-23) and 177.84 (C-28)] and literature values [28]. In HMBC spectrum, the H-1 proton signal at $\delta 3.80(1 \mathrm{H}, \mathrm{m})$ correlated with carbons $\mathrm{C}-2(\delta 36.79), \mathrm{C}-3(\delta 74.14), \mathrm{C}-9(\delta 53.06), \mathrm{C}-10(\delta$ 44.47), and C-25 ( $\delta 13.17)$; protons $\mathrm{H}-2$ at $\delta 1.72(1 \mathrm{H}, \mathrm{m}), \mathrm{H}-3$ at $\delta 3.67(1 \mathrm{H}, \mathrm{m}), \mathrm{H}-5$ at $\delta 1.87(1 \mathrm{H}, \mathrm{m})$, and $\mathrm{H}-25$ at $\delta 0.95(3 \mathrm{H}, \mathrm{s})$ correlated with carbon C-1 $(\delta 76.33)$; the $\mathrm{H}-3$ proton signal at $\delta 3.67(1 \mathrm{H}, \mathrm{m})$ correlated with carbons $C-1(\delta 76.33)$ and C-5 $(\delta 46.11)$; protons $\mathrm{H}-2$ at $\delta 1.80(1 \mathrm{H}, \mathrm{m})$ and $\mathrm{H}-24$ at $\delta 1.09$ $(3 \mathrm{H}, \mathrm{s})$ correlated with carbon C-3 $(\delta 74.14)$; protons $\mathrm{H}-5$ at $\delta 1.87(1 \mathrm{H}, \mathrm{m})$ and $\mathrm{H}-24$ at $\delta 1.09(3 \mathrm{H}, \mathrm{s})$ correlated with carbon C-23 ( $\delta 182.60)$; protons $\mathrm{H}-16$ at $\delta 1.44(1 \mathrm{H}, \mathrm{m}), \mathrm{H}-18$ at $\delta 1.65(1 \mathrm{H}, \mathrm{m})$, and $\mathrm{H}-22$ at $\delta 1.94(1 \mathrm{H}, \mathrm{m})$ correlated with carbon C-28 $(\delta 176.40)$; the correlations from $\mathrm{H}-29$ at $\delta 4.58(1 \mathrm{H}$, brs, $\mathrm{Ha})$ and $\delta 4.72(1 \mathrm{H}, \mathrm{brs}, \mathrm{Hb})$ to $\mathrm{C}-19(\delta 48.36), \mathrm{C}-20(\delta 151.77)$, and C-30 ( $\delta 19.49)$; the correlations from $\mathrm{H}-30$ at $\delta 1.70(3 \mathrm{H}, \mathrm{s})$ to $\mathrm{C}-19(\delta 48.36), \mathrm{C}-20(\delta 151.77)$, and C-29 $(\delta 110.41)$. These pieces of evidences further confirmed that the double bond was at C-20/C-29 and the two hydroxyl groups were at C-1 and C-3, respectively (Figure 4 and Table S2).

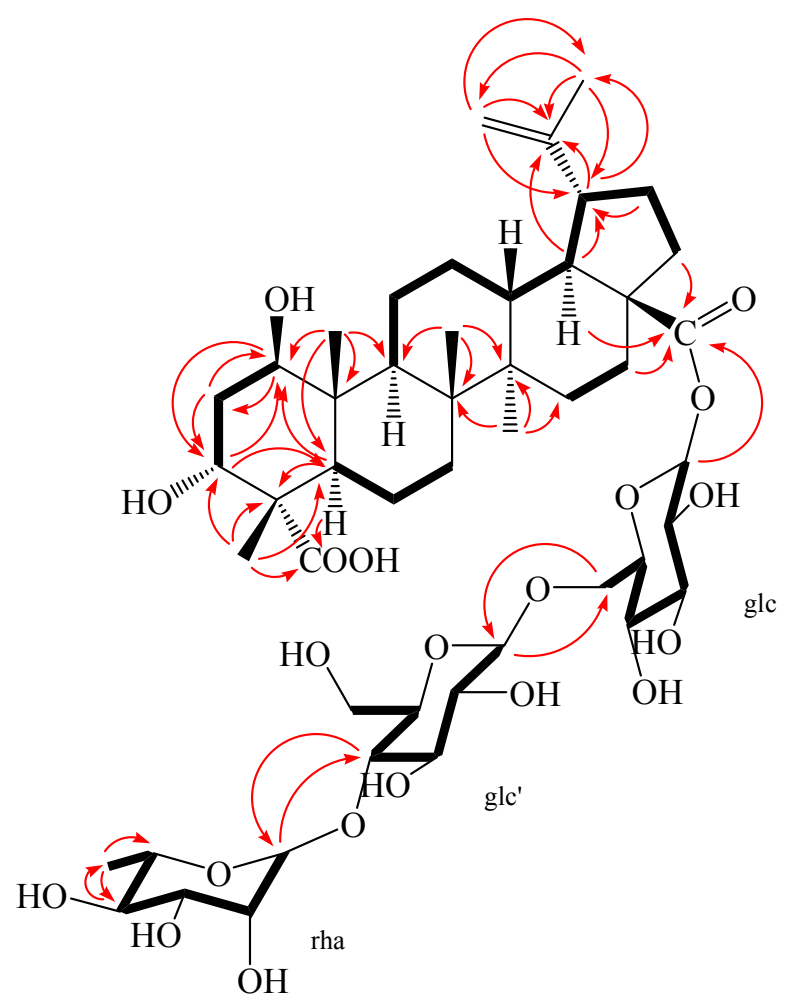

Figure 4. ${ }^{1} \mathrm{H}-{ }^{1} \mathrm{H}$ COSY (bold) and selected HMBC (arrow) correlations of 2.

The NOESY spectrum of 2 showed the correlations between the proton of $\mathrm{H}-1$ and $\mathrm{H}-2_{e q}, \mathrm{H}-1$ and $\mathrm{H}-5, \mathrm{H}-1$, and $\mathrm{H}-9$, suggesting that $\mathrm{H}-1$ had an axial orientation, which, in turn, suggested that the hydroxyl group at C-1 was $\beta$-positioned. Similarly, cross-peaks between $\mathrm{H}-24$ and $\mathrm{H}-25$, as well as $\mathrm{H}-3$, $\mathrm{H}-3$ and $\mathrm{H}-2_{\text {eq }}$, indicated that the methyl group (H-24) was axial and $\mathrm{H}-3$ was equatorial, which, in turn, suggested that the hydroxyl group at C-3 and carboxyl group at C-4 were $\alpha$-positioned (Figure 5). 
Alkaline hydrolysis of $\mathbf{2}$ with $5 \% \mathrm{KOH}$ in $\mathrm{MeOH}$ gave a sapogenol (2a), a colorless needle, $\mathrm{mp} 282.5^{\circ} \mathrm{C}$, together with a mixture of sugars. The sugar mixture was identified to be composed of D-glucose and L-rhamnose by thin-layer chromatography (TLC) with their authentic sample. The ${ }^{1} \mathrm{H}$ and ${ }^{13} \mathrm{C}$ NMR data of 2a (see Experimental Section) were the same as those of 1, which further confirmed that this aglycone (2a) was $1 \beta, 3 \alpha$-dihydroxy-lup-20(29)-en-23,28-dioic acid. Moreover, the HMBC correlations between the inner glc H-1 $(\delta 5.45)$ and C-28 of the aglycone $(\delta 176.40)$, between outer glc $\mathrm{H}-1^{\prime}(\delta 4.37)$ and inner glc C-6 ( $\left.\delta 69.55\right)$, between rha H-1" $(\delta 4.84)$ and glc C-4 ${ }^{\prime}(\delta 79.51)$ were observed (Figure 4). In addition, the NOESY correlations between the inner glc $\mathrm{H}-1$ and glc $\mathrm{H}-5$, between outer glc $\mathrm{H}-1^{\prime}$ and glc $\mathrm{H}-3^{\prime}$ as well as glc $\mathrm{H}-5^{\prime}$, between rha $\mathrm{H}-1^{\prime \prime}$ and rha $\mathrm{H}-2^{\prime \prime}$, rha $\mathrm{H}-5^{\prime \prime}$ and rha $\mathrm{H}-3^{\prime \prime}$, as well as rha H-6", rha H-4" and rha H-6", which further confirmed the inner glucose, outer glucose, and rhamnose were $\beta$-D, $\beta$-D, and $\alpha$-L positioned, respectively (Figure 5). These results suggest the sequence of sugar linkages of 2 . The carbon signals of the sugar moiety were superimposable on those of characteristic triterpene glycosides isolated from Acanthopanax species [4-7,25-28]. Consequently, the structure of 2 was determined as $1 \beta, 3 \alpha$-dihydroxy-lup-20(29)-en-23,28-dioic acid 28-O-[ $\alpha$-L-rhamnopyranosyl- $(1 \rightarrow 4)-\beta$-D-glucopyranosyl-( $1 \rightarrow 6)-\beta$-D-glucopyranosyl] ester, a new compound named acangraciliside $S$.

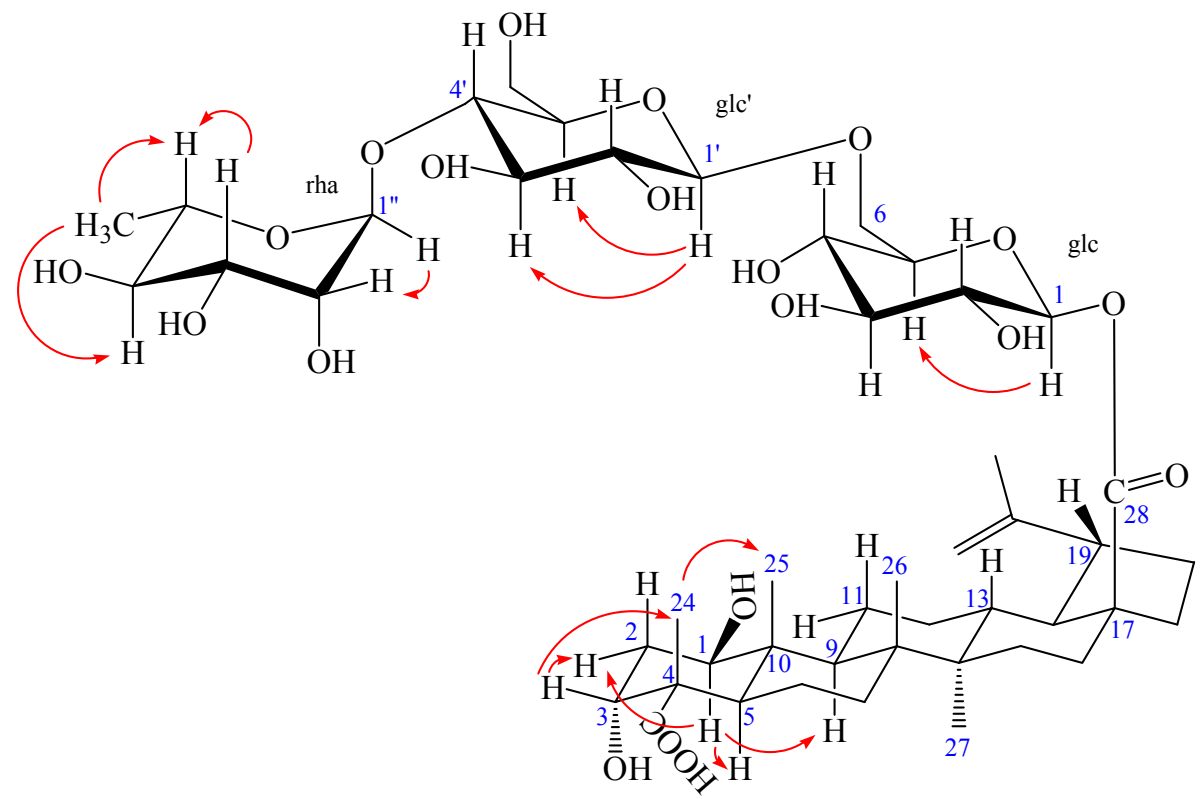

Figure 5. The key NOESY (arrow) correlations of 2.

Table 1. NMR spectral data of compounds 1-2.

\begin{tabular}{|c|c|c|c|c|}
\hline Position & $1 \delta_{C}^{a, c}$ & $\delta_{H}{ }^{a, d}[$ mult. $(J$ in $\mathrm{Hz})]$ & $2 \delta_{C} b, c$ & $\delta_{H}{ }^{b, d}[$ mult. $(J$ in $\mathrm{Hz})]$ \\
\hline \multicolumn{5}{|l|}{ Aglycone } \\
\hline 1 & 75.46 & $3.84(1 \mathrm{H}, \mathrm{dd}, 8.16,3.96)$ & 76.33 & $3.80(1 \mathrm{H}, \mathrm{m})$ \\
\hline 2 & 37.36 & $1.82(1 \mathrm{H}, \mathrm{m}) ; 1.87(1 \mathrm{H}, \mathrm{m})$ & 36.79 & $1.72(1 \mathrm{H}, \mathrm{m}) ; 1.80(1 \mathrm{H}, \mathrm{m})$ \\
\hline 3 & 73.99 & $3.82(1 \mathrm{H}, \mathrm{t}, 2.40)$ & 74.14 & $3.67(1 \mathrm{H}, \mathrm{m})$ \\
\hline 4 & 52.27 & - & 52.24 & - \\
\hline 5 & 45.25 & $1.95(1 \mathrm{H}, \mathrm{m})$ & 46.11 & $1.87(1 \mathrm{H}, \mathrm{m})$ \\
\hline 6 & 22.09 & $1.35(1 \mathrm{H}, \mathrm{m}) ; 1.57(1 \mathrm{H}, \mathrm{m})$ & 22.17 & $1.26(1 \mathrm{H}, \mathrm{m}) ; 1.58(1 \mathrm{H}, \mathrm{m})$ \\
\hline 7 & 35.19 & $1.31(1 \mathrm{H}, \mathrm{m}) ; 1.56(1 \mathrm{H}, \mathrm{m})$ & 35.09 & $1.30(1 \mathrm{H}, \mathrm{m}) ; 1.55(1 \mathrm{H}, \mathrm{m})$ \\
\hline 8 & 42.76 & - & 42.96 & - \\
\hline 9 & 52.98 & $1.72(1 \mathrm{H}, \mathrm{dd}, 10.08,2.68)$ & 53.06 & $1.72(1 \mathrm{H}, \mathrm{m})$ \\
\hline 10 & 44.33 & - & 44.47 & - \\
\hline 11 & 24.68 & $\begin{array}{c}1.32(1 \mathrm{H}, \mathrm{m}) ; 2.43(1 \mathrm{H} \\
\text { brd, } 9.80)\end{array}$ & 24.82 & $1.36(1 \mathrm{H}, \mathrm{m}) ; 2.28(1 \mathrm{H}, \mathrm{m})$ \\
\hline
\end{tabular}


Table 1. Cont.

\begin{tabular}{|c|c|c|c|c|}
\hline Position & $1 \delta_{C}^{a, c}$ & $\delta_{H}{ }^{a, d}$ [mult. $(J$ in $\left.\mathrm{Hz})\right]$ & $2 \delta_{C} b, c$ & $\delta_{H}{ }^{b, d}$ [mult. $(J$ in $\left.\mathrm{Hz})\right]$ \\
\hline 12 & 26.87 & $\begin{array}{c}1.12(1 \mathrm{H}, \mathrm{dd}, 10.52,3.76) ; 1.68 \\
(1 \mathrm{H}, \mathrm{m})\end{array}$ & 26.94 & $1.12(1 \mathrm{H}, \mathrm{m}) ; 1.68(1 \mathrm{H}, \mathrm{m})$ \\
\hline 13 & 39.14 & $2.34(1 \mathrm{H}, \mathrm{td}, 10.32,3.0)$ & 39.13 & $2.27(1 \mathrm{H}, \mathrm{m})$ \\
\hline 14 & 43.72 & - & 43.82 & - \\
\hline 15 & 30.75 & $1.20(1 \mathrm{H}, \mathrm{m}) ; 1.46(1 \mathrm{H}, \mathrm{m})$ & 30.86 & $1.15(1 \mathrm{H}, \mathrm{m}) ; 1.54(1 \mathrm{H}, \mathrm{m})$ \\
\hline 16 & 33.15 & $\begin{array}{c}1.48(1 \mathrm{H}, \mathrm{m}) ; 2.25(1 \mathrm{H}, \mathrm{dt}, \\
9.84,2.8)\end{array}$ & 32.95 & $1.44(1 \mathrm{H}, \mathrm{m}) ; 2.33(1 \mathrm{H}, \mathrm{m})$ \\
\hline 17 & 56.98 & - & 57.93 & - \\
\hline 18 & 50.30 & $1.64(1 \mathrm{H}, \mathrm{m})$ & 50.60 & $1.65(1 \mathrm{H}, \mathrm{m})$ \\
\hline 19 & 48.24 & $3.05(1 \mathrm{H}, \mathrm{td}, 8.76,4.0)$ & 48.36 & $3.00(1 \mathrm{H}, \mathrm{m})$ \\
\hline 20 & 151.89 & - & 151.77 & - \\
\hline 21 & 31.61 & $1.34(1 \mathrm{H}, \mathrm{m}) ; 1.90(1 \mathrm{H}, \mathrm{m})$ & 31.55 & $1.37(1 \mathrm{H}, \mathrm{m}) ; 1.94(1 \mathrm{H}, \mathrm{m})$ \\
\hline 22 & 37.84 & $1.48(1 \mathrm{H}, \mathrm{m}) ; 1.92(1 \mathrm{H}, \mathrm{m})$ & 37.68 & $1.48(1 \mathrm{H}, \mathrm{m}) ; 1.94(1 \mathrm{H}, \mathrm{m})$ \\
\hline 23 & 178.16 & - & 182.6 & - \\
\hline 24 & 17.92 & $1.17(3 \mathrm{H}, \mathrm{s})$ & 18.08 & $1.09(3 \mathrm{H}, \mathrm{s})$ \\
\hline 25 & 13.24 & $0.97(3 \mathrm{H}, \mathrm{s})$ & 13.17 & $0.95(3 \mathrm{H}, \mathrm{s})$ \\
\hline 26 & 17.31 & $0.99(3 \mathrm{H}, \mathrm{s})$ & 17.14 & $0.98(3 \mathrm{H}, \mathrm{s})$ \\
\hline 27 & 15.40 & $1.07(3 \mathrm{H}, \mathrm{s})$ & 15.10 & $1.03(3 \mathrm{H}, \mathrm{s})$ \\
\hline 28 & 177.84 & - & 176.40 & - \\
\hline 29 & 110.26 & $4.58(1 \mathrm{H}, \mathrm{m}) ; 4.72(1 \mathrm{H}, \mathrm{d}, 1.68)$ & 110.41 & $4.58(1 \mathrm{H}, \mathrm{brs}) ; 4.72(1 \mathrm{H}, \mathrm{brs})$ \\
\hline 30 & 19.72 & $1.71(3 \mathrm{H}, \mathrm{s})$ & 19.49 & $1.70(3 \mathrm{H}, \mathrm{s})$ \\
\hline \multicolumn{5}{|l|}{ C-28 O-glc } \\
\hline 1 & & & 95.26 & $5.45(1 \mathrm{H}, \mathrm{d}, 6.56)$ \\
\hline 2 & & & 74.00 & $3.33(1 \mathrm{H}, \mathrm{m})$ \\
\hline 3 & & & 78.28 & $3.42(1 \mathrm{H}, \mathrm{m})$ \\
\hline 4 & & & 70.95 & $3.43(1 \mathrm{H}, \mathrm{m})$ \\
\hline 5 & & & 78.06 & $3.54(1 \mathrm{H}, \mathrm{m})$ \\
\hline 6 & & & 69.55 & $\begin{array}{c}3.81(1 \mathrm{H}, \mathrm{m}) ; 4.11(1 \mathrm{H}, \mathrm{dd}, \\
9.48,1.36)\end{array}$ \\
\hline \multicolumn{5}{|c|}{$\operatorname{glc}^{\prime}(1 \rightarrow 6)$ glc } \\
\hline $1^{\prime}$ & & & 104.56 & $4.37(1 \mathrm{H}, \mathrm{d}, 6.28)$ \\
\hline $2^{\prime}$ & & & 75.32 & $3.23(1 \mathrm{H}, \mathrm{m})$ \\
\hline $3^{\prime}$ & & & 76.71 & $3.45(1 \mathrm{H}, \mathrm{m})$ \\
\hline $4^{\prime}$ & & & 79.51 & $3.53(1 \mathrm{H}, \mathrm{m})$ \\
\hline $5^{\prime}$ & & & 76.89 & $3.30(1 \mathrm{H}, \mathrm{m})$ \\
\hline $6^{\prime}$ & & & 61.90 & $3.65(1 \mathrm{H}, \mathrm{m}) ; 3.80(1 \mathrm{H}, \mathrm{m})$ \\
\hline \multicolumn{5}{|c|}{$\operatorname{rha}(1 \rightarrow 4) g l c^{\prime}$} \\
\hline $1^{\prime \prime}$ & & & 102.92 & $4.84(1 \mathrm{H}$, overlapped $)$ \\
\hline $2^{\prime \prime}$ & & & 72.44 & $3.81(1 \mathrm{H}, \mathrm{m})$ \\
\hline $3 "$ & & & 72.16 & $3.62(1 \mathrm{H}, \mathrm{m})$ \\
\hline $4^{\prime \prime}$ & & & 73.75 & $3.38(1 \mathrm{H}, \mathrm{m})$ \\
\hline $5 "$ & & & 70.64 & $3.95(1 \mathrm{H}, \mathrm{m})$ \\
\hline $6^{\prime \prime}$ & & & 17.84 & $1.25(3 \mathrm{H}, \mathrm{d}, 4.96)$ \\
\hline
\end{tabular}

Note: Assignments were performed by HMQC, HMBC, ${ }^{1} \mathrm{H}_{-}{ }^{1} \mathrm{H}$ COSY, and NOESY experiments; Glc: D-glucopyranosyl; Rha: L-rhamnopyranosyl; ${ }^{a}$ Measured in $\mathrm{CD}_{3} \mathrm{COCD}_{3} ;{ }^{\mathrm{b}}$ Measured in $\mathrm{CD}_{3} \mathrm{OD} ;{ }^{\mathrm{c}} 100 \mathrm{MHz}$; d $400 \mathrm{MHz}$.

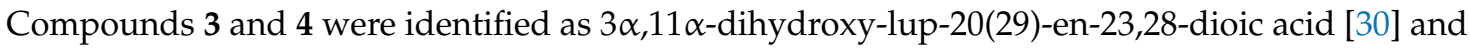
acankoreoside C [31], respectively, by comparing their NMR and mass spectral data with the literature values. (The ${ }^{1} \mathrm{H}$ - and ${ }^{13} \mathrm{C}-\mathrm{NMR}$ data of 3 and $\mathbf{4}$ see Supplementary Materials: Table S3)

Moreover, the cytotoxicity and inhibition of production of nitric oxide (NO) of selected isolates (1 and 3) from A. gracilistylus were investigated on LPS-stimulated BV2 microglias. Compounds 2 and 4 were excluded from biological evaluation because of sample shortage. As shown in Table 2, the production of $\mathrm{NO}$ was down-regulated moderately when their concentration was $80 \mu \mathrm{M}$ with the inhibition as $38.6 \%$ and $40.4 \%$, respectively. 
Table 2. Inhibitory effects of compounds 1 and 3 against LPS-Induced NO production in murine microglia BV2 cells ${ }^{\text {a }}$.

\begin{tabular}{ccc}
\hline Compounds & Inhibition & Cell Viability \\
\hline $\mathbf{1}$ & $38.6 \%$ in $80 \mu \mathrm{M}$ & $86.44 \%$ \\
$\mathbf{3}$ & $40.4 \%$ in $80 \mu \mathrm{M}$ & $83.90 \%$ \\
\hline
\end{tabular}

${ }^{\text {a }}$ Data is presented as the mean of three experiments \pm SD.

\section{Experimental Section}

\subsection{General Experimental Procedures}

Melting points (uncorrected) were measured using a Boetius micromelting point apparatus (Beijing Jingjing Science and Technology Co., Ltd., Beijing, China). ${ }^{1} \mathrm{H}-\mathrm{NMR}(400 \mathrm{MHz}),{ }^{13} \mathrm{C}-\mathrm{NMR}$ $(100 \mathrm{MHz})$ and $2 \mathrm{D}-\mathrm{NMR}$ were recorded at room temperature in $\mathrm{CD}_{3} \mathrm{COCD}_{3}$ or $\mathrm{CD}_{3} \mathrm{OD}$ using Bruker DRX-400 NMR spectrometer (Bruker Biospin, Zurich, Switzerland) and chemical shifts were presented in $\delta(\mathrm{ppm})$ values relative to tetramethylsilane (TMS) as internal standard. HR-ESI-MS was performed on an API QSTAR spectrometer (Agilent Technologies, Santa Clara, CA, USA). The high-speed countercurrent chromatography (HSCCC) instrument was performed in the present study using a model an TBE-300A HSCCC (Shanghai Tauto Biotech Co., Ltd., Shanghai, China). Semi-preparative HPLC was performed on an LC-20A liquid chromatograph (Shimadzu Technologies, Kyoto, Japan). Column chromatography was carried out on silica gel (200-300 mesh and 100-200 mesh, Qingdao Marine Chemical Co., Ltd., Qingdao, China), and Sephadex LH-20 (Merck, Darmstadt, Germany). RP-TLC was measured on a precoated RP- $18 \mathrm{~F}_{254 \mathrm{~s}}$ (Merck, Darmstadt, Germany) plates. TLC was conducted on self-made silica gel G (Qingdao Marine Chemical Industry, Qingdao, China) plates and spots were visualized by spraying with $10 \% \mathrm{H}_{2} \mathrm{SO}_{4}$ in ethanol $(v / v)$ followed by heating at $105^{\circ} \mathrm{C}$. The standard D-glucose and L-rhamnose were purchased from Beijing North Carolina Souren Biotechnology Research Institute (Beijing, China).

\subsection{Collection and Identification of Biological Materials}

The leaves of $A$. gracilistylus were collected from its natural habitat in Yuanling, Hunan Province, China, in July 2015 and identified by X.Q. Liu, the corresponding author of this work. A voucher specimen has been deposited in the Herbarium of Hunan University of Chinese Medicine, Hunan, China (no. 201507).

\subsection{Extraction and Isolation}

The dried, powdered leaves of A. gracilistylus (600 g) were extracted with methanol under reflux three times $(3 \times 3 \mathrm{~L})$. The solvent was then removed under reduced pressure to yield a residue $(120 \mathrm{~g})$, which was suspended in distilled water and successively partitioned with petroleum ether (PE, 60-90), EtOAc, and $n-\mathrm{BuOH}$, respectively. The EtOAc extract (28 g) was subjected to column chromatography (CC) on silica gel eluting with a gradient of $\mathrm{CHCl}_{3}-\mathrm{MeOH}(35: 1$ to $10: 1, v / v)$ to obtain the discolored fraction (E1). E1 was partitioned by HSCCC using two-phase solvent system composing of n-hexane-ethyl acetate-methanol-water (1:2:1.6:1, $v / v / v / v)$ with the flow rate of mobile phase of $2.0 \mathrm{~mL} / \mathrm{min}$, rotation rate of 800 r.p.m, to generate five fractions (F1-F5). Compounds $1(5.0 \mathrm{mg})$ and 3 (6.0 mg) were yielded from F2 $(25 \mathrm{mg})$ by using Pre-HPLC with $\mathrm{CH}_{3} \mathrm{CN}-\mathrm{H}_{2} \mathrm{O}(40: 60, v / v)$ for further purification. Similarly, the $n-\mathrm{BuOH}$ extract $(25 \mathrm{~g})$ was partitioned by HSCCC using two-phase solvent system composing of ethyl acetate-butanol-methanol-water (3:0.3:0.8:4, $v / v / v / v)$ with the flow rate of mobile phase of $2.0 \mathrm{~mL} / \mathrm{min}$, rotation rate of 900 r.p.m, to obtain five fractions (F6-F10). F6 (35 mg) was further chromatographed on Pre-HPLC with $\mathrm{CH}_{3} \mathrm{CN}-\mathrm{H}_{2} \mathrm{O}(25: 75, v / v)$ to produce two compounds 2 (11.3 $\mathrm{mg})$ and 4 (5.3 mg). 
Acangraciligenin S (1) was obtained as a colorless needle: mp. $282.6{ }^{\circ} \mathrm{C} ;{ }^{1} \mathrm{H}$ - and ${ }^{13} \mathrm{C}-\mathrm{NMR}$ data: (Table 1); (-)-HR-ESI-MS $m / z 501.3221$ [M - H] ${ }^{-}$(calcd. for $\mathrm{C}_{30} \mathrm{H}_{45} \mathrm{O}_{6}$ : 501.3222).

Acangraciliside S (2) was obtained as a white amorphous powder: mp. $230.5{ }^{\circ} \mathrm{C} ;{ }^{1} \mathrm{H}$ - and ${ }^{13} \mathrm{C}-\mathrm{NMR}$ data: (Table 1); (-)-HR-ESI-MS $m / z$ $971.4865[\mathrm{M}-\mathrm{H}]^{-}$(calcd. for $\mathrm{C}_{48} \mathrm{H}_{75} \mathrm{O}_{20}$ : 971.4857).

\subsection{Alkaline Hydrolysis of $\mathbf{2}$}

Compound $2(10 \mathrm{mg})$ was hydrolyzed with $8 \mathrm{~mL}$ of $5 \% \mathrm{KOH}$ in $\mathrm{MeOH}$ for $2 \mathrm{~h}$ at $80^{\circ} \mathrm{C}$. The reaction mixture was neutralized with $2 \mathrm{M} \mathrm{HCl}$ in $\mathrm{H}_{2} \mathrm{O}$ and extracted with EtOAc. The aqueous layer was filtered, concentrated and chromatographed on TLC plate in which D-glucose and L-rhamnose were detected by comparing with standard samples [4]. The EtOAc layer was evaporated in vacuo and the residue was performed on a preparative HPLC column by using elution with $\mathrm{CH}_{3} \mathrm{CN}-\mathrm{H}_{2} \mathrm{O}(40: 60, v / v)$ to obtain sapogenol fraction $2 \mathrm{a}(2 \mathrm{mg})$.

Compound 2a: Colorless needles, m.p. $282.5{ }^{\circ} \mathrm{C} .{ }^{1} \mathrm{H}-\mathrm{NMR}\left(400 \mathrm{MHz}, \mathrm{CD}_{3} \mathrm{COCD}_{3}\right)$ 8: $3.84(1 \mathrm{H}, \mathrm{dd}$, $J=8.16,3.96 \mathrm{~Hz}, \mathrm{H}-1), 3.82(1 \mathrm{H}, \mathrm{t}, J=2.40 \mathrm{~Hz}, \mathrm{H}-3), 1.95(1 \mathrm{H}, \mathrm{m}, \mathrm{H}-5), 1.72(1 \mathrm{H}, \mathrm{m}, \mathrm{H}-9), 2.34(1 \mathrm{H}, \mathrm{td}$, $J=10.32,3.0 \mathrm{~Hz}, \mathrm{H}-13), 1.64(1 \mathrm{H}, \mathrm{m}, \mathrm{H}-18), 3.05(1 \mathrm{H}, \mathrm{td}, J=8.76,4.0 \mathrm{~Hz}, \mathrm{H}-19), 1.17$ (3H, s, H-24), 0.97 (3H, s, H-25), 0.99 (3H, s, H-26), 1.08 (3H, s, H-27), 4.59 (1H, m, H-29a), 4.73 (1H, d, J = 1.68 Hz, H-29b), $1.71(3 \mathrm{H}, \mathrm{s}, \mathrm{H}-30) ;{ }^{13} \mathrm{C}-\mathrm{NMR}\left(100 \mathrm{MHz}, \mathrm{CD}_{3} \mathrm{COCD}_{3}\right)$ 8: 75.45 (C-1), 37.35 (C-2), 73.98 (C-3), 52.26 (C-4), 45.23 (C-5), 22.08 (C-6), 35.18 (C-7), 42.75 (C-8), 52.97 (C-9), 44.32 (C-10), 24.66 (C-11), 26.85 (C-12), 39.13 (C-13), 43.71 (C-14), 30.73 (C-15), 33.14 (C-16), 56.96 (C-17), 50.29 (C-18), 48.22 (C-19), 151.88 (C-20), 31.59 (C-21), 37.82 (C-22), 178.14 (C-23), 17.90 (C-24), 13.23 (C-25), 17.29 (C-26), 15.38 (C-27), 177.82 (C-28), 110.25 (C-29), 19.70 (C-30).

\subsection{MTT Assay for Cell Viability}

BV2 microglias were maintained at $5 \times 10^{5}$ cells $/ \mathrm{mL}$ in Dulbecco minimum essential medium (DMEM) medium supplemented with $10 \%$ heat-inactivated fetal bovine serum (FBS), penicillin $\mathrm{G}(100 \mathrm{U} / \mathrm{mL})$, streptomycin $(100 \mathrm{mg} / \mathrm{L})$, and L-glutamine $(2 \mathrm{mM})$ and incubated at $37{ }^{\circ} \mathrm{C}$ in a humidified atmosphere containing $5 \% \mathrm{CO}_{2}$. Cell viability was determined by adding $100 \mathrm{mg} / \mathrm{mL}$ of 3-[4,5-dimethylthiazol-2-yl]-2,5-diphenyltetrazolium bromide (MTT) to $1 \mathrm{~mL}$ of a cell suspension $\left(1 \times 10^{5}\right.$ cells $/ \mathrm{mL}$ in 96-well plates) and incubated for $30 \mathrm{~min}$. The formazan formed was dissolved in acidic 2-propanol, and the optical density was measured at $540 \mathrm{~nm}$.

\subsection{Nitrite Assay}

The concentration of nitric oxide (NO) in the conditioned media was determined by a method based on the Griess reaction [32]. An aliquot of each supernatant $(100 \mathrm{~mL})$ was mixed with the same volume of Griess reagent $(0.1 \%(w / v) N$-(1-naphathyl)-ethylenediamine and $1 \%(w / v)$ sulfanilamide in $5 \%(v / v)$ phosphoric acid) for $10 \mathrm{~min}$ at room temperature. The absorbance of the final product was measured spectrophotometrically at $540 \mathrm{~nm}$ using an enzyme-linked immunosorbent assay (ELISA) plate reader. The nitrite concentration in the samples was determined from a standard curve of sodium nitrite prepared in phenol red-free DMEM.

\subsection{Statistical Analysis}

All values are expressed as the mean \pm S.D. Differences between mean values of normallydistributed data were assessed with one-way analysis of variance (ANOVA) (Newman Keuls $t$-test). Statistical analysis was performed using GraphPad Prism software, version 3.03 (GraphPad Software Inc., San Diego, CA, USA). Statistical significance was accepted at $p<0.05$.

\section{Conclusions}

In summary, in this work, a phytochemical study on the leaves of A. gracilistylus (Araliaceae) by using HSCCC-HPLC combinatorial chromatography method resulted in the discovery of four 
lupane-triterpenoids, including two new compounds, acangraciligenin S (1) and acangraciliside

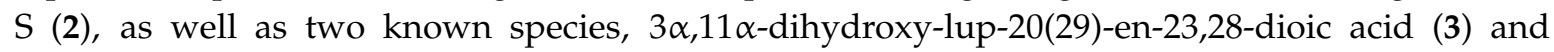
acankoreoside $C(4)$. Two selected compounds were also evaluated for their inhibitory activity against lipopolysaccharide (LPS)-induced nitric oxide (NO) production in murine microglia BV2 cells. Compounds $\mathbf{1}$ and $\mathbf{3}$ showed moderate abilities to inhibit NO production and had no influence on cell viability, as determined by the MTT method.

Supplementary Materials: The following ${ }^{1} \mathrm{H}-\mathrm{NMR},{ }^{13} \mathrm{C}-\mathrm{NMR}$, 2D-NMR, ESI-MS, and HR-ESI-MS spectra are available as supporting data. Supplementary materials are available online.

Acknowledgments: This project was supported financially by the Natural Science Foundation of Hunan Province, China (grant 11JJ2042) and the Key Projects of Changsha City Science and Technology Bureau (Grant k1403122-31).

Author Contributions: Xiang-Qian Liu designed the experiments and revised the paper; Xiao-Jun Li and Qin-Peng Zou performed the experiments, analyzed the data, and wrote the paper; Xiang Wang, Mao-Fang Lu, and Sung-Kwon Ko help to analyze data of experiment; Kwan-Woo Kim and Youn-Chul Kim contributed to bioassay reagents, materials and analyzed the data; and Chang-Soo Yook revised the paper. All authors read and approved the final manuscript.

Conflicts of Interest: The authors declare no conflict of interest. The founding sponsors had no role in the design of the study; in the collection, analyses, or interpretation of data; in the writing of the manuscript; or in the decision to publish the results.

\section{References}

1. Chinese Pharmacopoeia Commission. Chinese Pharmacopoeia of the People's Republic of China; Medical Science and Technology Press: Beijing, China, 2015; Volume 1, p. 79.

2. Ni, N.; Liu, X.Q. Advances in studies on plants of Acanthopanax Miq. in Araliaceae. Chin. Tradit. Herb. Drugs 2006, 37, 1895-1900.

3. Zhang, B.X.; Li, N.; Zhang, Z.P.; Liu, H.B.; Zhou, R.R.; Zhong, B.Y.; Zou, M.X.; Dai, X.H.; Xiao, M.F.; Liu, X.Q.; et al. Protective effect of Acanthopanax gracilistylus-extracted Acankoreanogenin A on mice with fulminant hepatitis. Int. Immunopharmacol. 2011, 11, 1018-1023. [CrossRef] [PubMed]

4. Yook, C.S.; Liu, X.Q.; Chang, S.Y.; Park, S.Y.; Nohara, T. Lupane-triterpene glycosides from the leaves of Acanthopanax gracilistylus. Chem. Pharm. Bull. 2002, 50, 1383-1385. [CrossRef] [PubMed]

5. Liu, X.Q.; Chang, S.Y.; Park, S.Y.; Nohara, T.; Yook, C.S. A new lupane-triterpene glycoside from the leaves of Acanthopanax gracilistylus. Arch. Pharm. Res. 2002, 25, 831-836. [CrossRef] [PubMed]

6. Liu, X.Q.; Chang, S.Y.; Yook, C.S. Lupane-triterpenoids from the leaves of Acanthopanax gracilistylus. J. Lanzhou Univ. Nat. Sci. 2006, 42, 86-91.

7. Zou, Q.P.; Liu, X.Q.; Lee, H.K.; Oh, O.J. Lupane-triterpenoids from the methanol extracts of leaves of Acanthopanax gracilistylus W. W. Smith. J. Lanzhou Univ. Nat. Sci. 2011, 47, 120-126.

8. Tang, X.Y.; Ma, Y.C.; Li, P.J. Separation and identification of the anti-inflammatory diterpene from the root cortices of Acanthopanax gracilistylus W. W. Smith. Chin. J. Chin. Mater. Med. 1995, 20, 231-232.

9. Wu, Z.Y.; Zhang, Y.B.; Zhu, K.K.; Luo, C.; Zhang, J.X.; Cheng, C.R.; Feng, R.H.; Yang, W.Z.; Zeng, F.; Wang, Y.; et al. Anti-inflammatory diterpenoids from the root bark of Acanthopanax gracilistylus. J. Nat. Prod. 2014, 77, 2342-2351. [CrossRef] [PubMed]

10. Liu, X.Q.; Zhang, C.Y.; Yin, W.J.; Liu, Z.X.; Yook, C.S. Analysis of volatile oil components of Acanthopanax gracilistylus. Chin. Tradit. Herb. Drugs 2001, 32, 1074-1075.

11. Liu, X.Q.; Park, S.Y.; Yook, C.S. Studies on the constituents of the stem barks of Acanthopanax gracilistylus W. W. Smith. Nat. Prod. Sci. 2002, 8, 23-25.

12. Liu, X.Q.; Yook, C.S.; Chang, S.Y. Chemical constituents of Acanthopanax gracilistylus. Chin. Tradit. Herb. Drugs 2004, 35, 250-252.

13. Zhang, J.Y.; Pu, S.B.; Qian, S.H.; Liu, D. New cerebrosides from Acanthopanax gracilistylus. Chin. J. Nat. Med. 2011, 9, 105-107.

14. Liu, X.Q.; Chang, S.Y.; Ro, S.H.; Yook, C.S. Constituents of Acanthopanax gracilistylus W. W. Smith. Nat. Med. 2002, 56, 215-216.

15. An, S.Y.; Qian, S.H.; Jiang, J.Q.; Wang, K.C. Chemical constituents in leaves of Acanthopanax gracilistylus. Chin. Tradit. Herb. Drugs 2009, 40, 1528-1534. 
16. Xian, L.N.; Qian, S.H.; Li, Z.L. Studies on the chemical constituents from the stems of Acanthopanax gracilistylus. J. Chin. Med. Mater. 2010, 33, 538-542.

17. Zhang, J.Y.; Pu, S.B.; Qian, S.H.; Liu, D.; Wang, K.C. Studies on the chemical constituents in fruits of Acanthopanax gracilistylus. J. Chin. Med. Mater. 2011, 34, 226-229.

18. Song, X.H.; Xu, G.J.; Jin, R.L. Studies on chemical constituents of the root bark of Acanthopanax gracilistylus. J. Chin. Pharm. Univ. 1987, 18, 203-204.

19. Dai, L.; Liu, X.Q.; Xie, X.; Liu, H.Y. Characterization of stereostructure by X-ray and technology of extracting in combination hydrolysis in situ of acankoreanogenin from leaves of Acanthopanax gracilistylus W. W. Smith. J. Cent. South Univ. 2014, 21, 3063-3070. [CrossRef]

20. Shan, B.E.; Zeki, K.; Sugiura, T.; Yoshida, Y.; Yamashita, U. Chinese medicinal herb, Acanthopanax gracilistylus, extract induces cell cycle arrest of human tumor cells in vitro. Cancer Sci. 2000, 91, 383-389. [CrossRef]

21. Shan, B.E.; Si, C.Y.; Zhang, J.Z. The Isolation of Anti-tumor Component of Acanthopanax gracilistylus. Teratog. Carcinog. Mutagen. 2004, 4, 203-205.

22. Li, X.J.; Dai, L.; Li, Z.; Zhang, X.D.; Liu, X.Q.; Zou, Q.P.; Xie, X. Anti-inflammatory activities of lupanetriterpenoids in vitro and their phytochemical fingerprinting from leaves of Acanthopanax gracilistylus. Nat. Prod. Sci. 2015, 21, 104-110.

23. Zou, Q.P.; Liu, X.Q.; Huang, J.J.; Yook, C.S.; Whang, W.K.; Lee, H.K.; Kwon, O.K. Inhibitory effects of lupane-type triterpenoid saponins from the leaves of Acanthopanax gracilistylus on lipopolysaccharideinduced TNF- $\alpha$, IL-1 $\beta$ and high-mobility group box 1 release in macrophages. Mol. Med. Rep. 2017, 16, 9149-9156. [PubMed]

24. Liu, X.Q.; Zou, Q.P.; Huang, J.J.; Yook, C.S.; Whang, W.K.; Lee, H.K.; Kwon, O.K. Inhibitory effects of $3 \alpha$-hydroxy-lup-20(29)-en-23, 28-dioic acid on lipopolysaccharide-induced TNF- $\alpha$, IL-1 $\beta$, and the high mobility group box 1 release in macrophages. Biosci. Biotechnol. Biochem. 2017, 81, 1305-1313. [CrossRef] [PubMed]

25. Yook, C.S.; Kim, I.H.; Hahn, D.R.; Nohara, T.; Chang, S.Y. A lupane-triterpene glycoside from leaves of two Acanthopanax. Phytochemistry 1998, 49, 839-843. [CrossRef]

26. Chang, S.Y.; Yook, C.S.; Nohara, T. Two new lupane-triterpene glycosides from leaves of Acanthopanax koreanum. Chem. Pharm. Bull. 1998, 46, 163-165. [CrossRef]

27. Nhiem, N.X.; Tung, N.H.; Van Kiem, P.; Van Minh, C.; Ding, Y.; Hyun, J.H.; Kang, H.K.; Kim, Y.H. Lupane triterpene glycosides from leave of Acanthopanax koreanum and their cytotoxic activity. Chem. Pharm. Bull. 2009, 57, 986-989. [CrossRef] [PubMed]

28. Nhiem, N.X.; Van Kiem, P.; Van Minh, C.; Tai, B.H.; Yen, P.H.; Tung, N.H.; Tung, N.H.; Hyun, J.H.; Kang, H.K.; Kim, Y.H. Lupane-type triterpene glycosides from the leaves of Acanthopanax koreanum and their in vitro cytotoxicity. Planta Med. 2010, 76, 189-194. [CrossRef] [PubMed]

29. Jahan, N.; Ahmed, W.; Malik, A. A lupene-type triterpene from Mimusops elengi. Phytochemistry 1995, 39, 255-257. [CrossRef]

30. Lischewski, M.; Ty, P.D.; Schmidt, J.; Preiss, A.; Phiet, H.V.; Adam, G. Natural products from Vietnamese

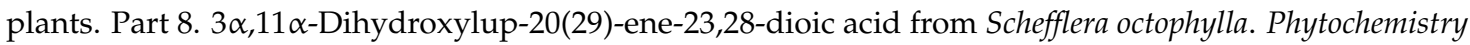
1984, 23, 1695-1697. [CrossRef]

31. Chang, S.Y.; Yook, C.S.; Nohara, T. Lupane-triterpene glycosides from leaves of Acanthopanax koreanum. Phytochemistry 1999, 50, 1369-1374. [CrossRef]

32. Titheradge, M.A. The enzymatic measurement of nitrate and nitrite. Methods Mol. Biol. 1998, 100, 83-91. [PubMed]

Sample Availability: Samples of the compounds are available from the authors. 